\title{
День памяти 6. Игорь Сергеевич Шевцов
}

\author{
А.И. Зарытовская, М. В. Деревягина \\ Воронежский государственньй университет, Российская Федерация \\ (394018, г. Воронеж, Университетская пл., 1)
}

\begin{abstract}
Аннотация: Цель - представить основные этапы жизни и деятельности выпускника географического факультета, кандидата географических наук, доцента кафедры социально-экономической географии и регионоведения ВГУ И.С. Шевцова.

Ключевые слова: И.С. Шевцов, биографические данные, кафедра, студент, аспирант, Ученый, Преподаватель, Человек, время, семья, Воронеж, Чертовицы, литература.

Для цитирования: Зарытовская А. И., Деревягина М. В. День памяти 6. Игорь Сергеевич Шевцов // Вестник Воронежского государственного университета. Серия География. Геоэкология, 2020, № 4, c. 101-105. DOI: https://doi.org/10.17308/geo.2020.4/3071
\end{abstract}

Помимо личных впечатлений авторов об Игоре Сергеевиче Шевцове, в статье использованы воспоминания членов его семьи, в том числе публикация ближайшей родственницы - В. К. Жучковой «Родная кровь» [2] и там же, подготовленные к печати И.С. Шевцовым «Сталинградский дневник» и «Письма с фронта» его брата Александра Петровича Кретова под общим названием «Нас не надо жалеть...» [3], а также материалы Г. Т. Гришина и Ю. В. Поросенкова.

Родился И.С. Шевцов 10 октября 1935 года в городе Воронеже. Его мама, Ольга Кретова, журналист, член Союза писателей СССР, отец - Сергей Шевцов, ее коллега. Вскоре после рождения сына обкомом партии он был переведен из Воронежа в Курск заведующим редакцией областной газеты, затем отправлен на лесоповал в тайгу Европейской России, где в 1937 году простудился и умер от воспаления легких; реабилитирован посмертно. К великому сожалению в 1930-е годы такова была участь немалого количества советских граждан. Но это нисколько не отразилось на взглядах и мировоззрении И. С. Шевцова, поскольку решающим было материнское влияние. Судя по ее произведениям, документальным воспоминаниям о жизни и творчестве, она была настоящим патриотом, приверженцем советской власти, в станов- ление которой внесла большой вклад своей общественной, журналистской и литературной деятельностью.

Большое влияние в воспитании Игоря Сергеевича как личности и человека сыграли также дедушка и бабушка по материнской линии. Они были учителями в начальной школе, построенной в селе Чертовицы (тогда Березовского района Воронежской области) в 1903 году. Отец его мамы - Жучков Капитон Алексеевич в течение сорока лет был одновременно бессменным директором этой школы. Его семья насчитывала десять детей; здесь Игорь Сергеевич провел много счастливых дней в раннем детстве, а затем отдыхал все летние каникулы, учась в школе и в университете. Он до конца дней с большой радостью и любовью вспоминал обстановку и царящие в семье тепло дома, окруженного прекрасным пришкольным участком, окаймленным белой акацией, вишневым садом и, конечно, неповторимые красоты окрестностей села Чертовицы с лесом, лугами, грибами, ягодами, дикими яблоками и грушами, реку Воронеж. Все это способствовало формированию у Игоря Сергеевича замечательных человеческих качеств доброты, интеллигентности, уважительного отношения к студентам и сотрудникам, умение понимать и видеть красоту слова и природы.

() Зарытовская А.И., Деревягина М.В., 2020

凶 Деревягина Мария Владимировна, e-mail: $\underline{m}$ derevyagina@mail.ru

(c) (i) Контент доступен под лицензией Creative Commons Attribution 4.0 License. 
Немалую роль в его жизни сыграл старший брат - Александр Петрович Кретов. Они с взаимной любовью относились друг к другу, но их общение было недолгим, так как Александр Петрович, окончив в 1941 году среднюю школу № 3 в Воронеже, ушел на фронт. Воевал он на Сталинградском фронте, командовал взводом, ротой, был ранен. После лечения в саратовском госпитале в течение марта 1943 по март 1945 года прошел боевой путь от Волги до западной Латвии. Здесь, в звании гвардии лейтенанта, принимал участие в ликвидации окруженной Курземской группировки гитлеровцев. 28 марта 1945 года, поднимая в атаку свою стрелковую роту близ латвийского города Добеле, А. П. Кретов был убит осколками снаряда, разорвавшегося рядом с ним. Награжден орденом Славы 3-й степени и медалью за оборону Сталинграда.

По возрасту Игорь Сергеевич относился к детям войны. Гибель близких наложила на это поколение вместе с взрослыми большой отпечаток. Как святая реликвия хранились и хранятся в семье И. С. Шевцова «Сталинградский дневник» и «Письма с фронта», которые он читал и перечитывал, учась у брата мужеству и любви к Родине. Эти материалы Игорь Сергеевич предоставил для публикации журналу «Подъем», посвященному 60-й годовщине Великой Победы [3]. Он озаглавил их первой строкой стихотворения замечательного поэта-фронтовика С. Гудзенко, безвременно умершего от ран вскоре после войны, «Нас не надо жалеть...». В них отражен главный смысл дневника и писем брата - одного из героев войны, защитивших Родину и всех нас от врага в священной битве с фашизмом и отдавших за это свои жизни.

Завершив в 1952 году обучение в воронежской средней школе № 3, И. С. Шевцов поступает учиться в Воронежский государственный университет на географический факультет. На выбор факультета, вероятно, повлияла сестра его мамы - Вера Капитоновна Жучкова, окончившая географический факультет Московского государственного университета имени М. В. Ломоносова, а затем, защитив кандидатскую диссертацию, долгие годы работавшая в нем старшим научным сотрудником, доцентом [2]. После успешного прохождения учебы в университете И. С. Шевцов получает специальность «экономико-географ». Некоторое время работает в Воронежской областной плановой комиссии (сокращенно-облплан). Этот период в своей трудовой деятельности в смысле профессио- нального роста он считал очень важным. Вот почему сотрудничество с облпланом он не прерывал в течение долгих лет. Без преувеличения можно сказать, что работа в облплане была для выпускника ВГУ еще одним «университетом», с учетом той огромной роли, которую играло планирование в создании социалистической экономики в нашей стране (до декабря 1991 года СССР), в организации и управлении ею с помощью главного инструмента, какими былм государственные планы текущие и перспективные, отраслевые и территориальные.

В конце 1950-х годов И. С. Шевцова принимают на работу в ВГУ в качестве преподавателя кафедры экономической географии, которой заведовал доцент, затем профессор, доктор географических наук Г. Т. Гришин [1]. Он же руководил открытой в 1960 году аспирантурой. И.С. Шевцов совмещал обучение в аспирантуре с учебным процессом, что существенно подняло его научно-педагогическую квалификацию. Тема диссертационной работы И. С. Шевцова на звание кандидата географических наук, успешно защищенная им в 1966 году, была очень актуальной и называлась «Развитие и размещение малых и средних городских поселений Воронежской области» [1]. Она носила не только научный, но и конструктивный характер. К началу 1960-х годов во всей стране остро обозначилась проблема чрезмерной концентрации промышленного производства и других отраслей народного хозяйства в больших и крупных городах - столичных и областных центрах. В то же время, малые города (с численностью населения до 50 тыс. человек и средние - от 50,1 до 100 тыс. человек), развивались очень медленно. Но именно они играют важную роль в развитии сельской местности, территориально находясь поблизости от сельских поселений, в сближении уровня жизни города и села. Благодаря научным экономико-географическим исследованиям важной проблемы, результаты которых учитывались государством при ее решении, в 1970-е и 1980-е годы произошли серьезные сдвиги в экономическом и социальном развитии малых и средних городов страны и Воронежской области. В последующие годы, и прежде всего в 1990-е, в связи с переходом к рыночной экономике от плановой социалистической, когда в одночасье отказались от планирования и полноценного государственного управления, вместо того, чтобы в переходный период (который отсутствовал в стране) сочетать их с элементами рынка, включающим в себя хозяйственный расчет, 
это привело к жестокому экономическому кризису в целом, в том числе малых и средних городских поселений и сельских территорий. Между тем, в стране есть опыт очень успешного переходного периода от капитализма к социализму - новая экономическая политика (НЭП), проводившаяся в 1921-1925 годах, и позволившая к концу ее осуществления выйти по многим экономическим показателям на уровень 1913 года. Можно привести еще один пример такого же успешного сочетания рынка и усовершенствованного планирования в период проведения под руководством Премьерминистра СССР А.Н. Косыгина экономической реформы в годы восьмой пятилетки (1966-1970). Она, к сожалению, была свернута. Может быть, благодаря ее осуществлению, удалось бы избежать распада СССР и других тяжелых экономических и социальных потрясений, которые переживали страна и народ в 1990-е годы. Пока что многие из них не удалось преодолеть, все еще острыми остаются проблемы развития малых и средних городов и сельских территорий, что требует внимания ученых к их разработке уже в новых экономических и социальных условиях страны и регионов.

Научная работа И. С. Шевцова была тесно связана с общекафедральными научными исследованиями, проводившимися под руководством заведующего кафедрой экономической географии, профессора Г. Т. Гришина. Они были направлены на разработку вопросов низового административного, внутриобластного районирования и микрорайонирования Воронежской области, внутриобластного дробного районирования Черноземного Центра для целей сельского хозяйства, общетеоретических проблем экономической географии, территориальной организации производительных сил Центрально-Черноземного района, а также общества и управления, территориальной структуре основного социально-экономического района (вопросы теории), производственного и социальнокультурного потенциала нашего региона. Эти исследования нашли отражение в ряде коллективных кафедральных монографиях при активном участии И. С. Шевцова, в научных статьях и методических публикациях. Всего им было опубликовано более 50 научных и методических работ. Назовем лишь некоторые, наиболее крупные и значимые из них: Советский Союз. Российская Федерация. Центральная Россия. Черноземный Центр. Это многотомное географическое описание страны (1970 год); ответственный редактор - Ф.Н. Мильков.
И. С. Шевцов является одним из авторов. Им был написан ряд разделов Воронежской энциклопедии, изданной в двух томах в Воронеже (20082009 годы), монографии «Земля Воронежская» (под ред. проф. В. И. Федотова, 2006 год), составлено несколько карт и дано их описание в Атласекниге Воронежской области (под ред. проф. В. И. Федотова, 2013 год) и многие другие. Его публикации характеризуются новизной, научной глубиной, разнообразием тематики и поставленных в них проблем.

Помимо таланта ученого, И. С. Шевцов обладал высоким педагогическим мастерством. Нам посчастливилось учиться у него. Он читал нам лекции и вел семинарские занятия по следующим дисциплинам: 1) экономическая география СССР: Союзные республики (после распада Советского Союза в 1991 году - экономическую и социальную географию России); 2) экономическую географию Центрально-Черноземного экономического района; 3 ) геоурбанистику; 4) основы экономики и территориальной организации промышленности региона; 5) географию ЦЧР.

Во время лекций Игорь Сергеевич как бы размышлял вслух над излагаемым материалом. Теоретические положения темы иллюстрировал многочисленными доказательствами, демонстрируя огромные знания преподаваемых курсов. Содержание лекций транслировал студентам отличным русским языком, часто цитировал классиков русской литературы. Особенно он любил произведения Н. В. Гоголя.

И. С. Шевцов хорошо играл в шахматы (имел высокий разряд), любил музыку, особенно русские романсы и сам очень хорошо пел. Его лекции носили позитивный характер, они несли добро и культуру слушателям. У него складывались очень доброжелательные отношения со всеми сотрудниками кафедры и нашего факультета. И мы все относились к нему с глубоким уважением и симпатией. Он ушел из жизни после тяжелой болезни 9 марта 2013 года. В последнее время уже не работал, однако студенты постоянно обращались к нему за консультацией и он никому не отказывал в помощи. У И. С. Шевцова осталась замечательная семья; его дети и внуки учились на нашем факультете. Вспоминая о нашем Учителе, Сотруднике, Коллеге, мы искренне благодарим его и помним за знания, которые он нам дал, за совместную работу, за высокие человеческие качества и профессионализм в работе. 


\section{СПИСОК ЛИТЕРАТУРЫ}

1. Гришин Г.Т., Поросенков Ю.В. Кафедра социально-экономической географии и регионоведения: история и современность // Вестник Воронежского государственного университета. Серия География. Геоэкология, 2004, № 2, с. 42-62.
2. Жучкова В. К. Родная кровь // Подъем, 2005, № 5.

3. Кретов А.П. Нас не надо жалеть... // Подъем, 2005, № 5 .

Конфликт интересов: Авторы декларируют отсутствие явных и потенциальных конфликтов интересов, связанных с публикацией настоящей статьи.

Поступила в редакичю 27.01.2020

Принята к публикации 20.11.2020

\title{
HISTORY OF SCIENCE
}

\section{Remembrance Day 6. Igor Sergeevich Shevtsov}

\author{
A. I. Zarytovskaya, M. V. Derevyagina ${ }^{凶}$ \\ Voronezh State University, Russian Federation \\ (1, Universitetskaya pl., Voronezh, 394018)
}

\begin{abstract}
The purpose is to present the main stages of life and activity of a postgraduate student of the Faculty of Geography, Candidate of Geographical Sciences, Associate Professor of the Department of social and economic geography and regional studies of VSU I.S. Shevtsov.

Key words: I. S. Shevtsov, biographical data, Department, student, postgraduate student, Scientist, Teacher, Person, time, family, Voronezh, Chertovitsy, literature.

For citation: Zarytovskaya A. I., Derevyagina M. V. Remembrance Day 6. Igor Sergeevich Shevtsov. Vestnik Voronezskogo gosudarstvennogo universiteta. Seria Geografia. Geoekologia, 2020, No. 4, pp. 101105. (In Russ.) DOI: https://doi.org/10.17308/geo.2020.4/3071
\end{abstract}

\section{REFERENCES}

1. Grishin G. T., Porosenkov Yu. V. Kafedra sotsial'noekonomicheskoy geografii i regionovedeniya: istoriya $\mathrm{i}$ sovremennost' [Department of socio-economic geography and regional studies: history and modernity]. Vestnik Voronezskogo gosudarstvennogo universiteta. Seria Geografia. Geoekologia, 2004, no. 2, pp. 42-62. (In Russ.)
2. Zhuchkova V.K. Rodnaya krov' [Native blood]. Pod"em, 2005, no. 5. (In Russ.)

3. Kretov A.P. Nas ne nado zhalet'... [You shouldn't feel sorry for us ...]. Pod"em, 2005, no. 5. (In Russ.)

Conflict of interests: The authors declare no information of obvious and potential conflicts of interest related to the publication of this article.

Received: 27.01.2020

Accepted: 20.11.2020

Aleksandra I. Zarytovskaya

Cand. Sci. (Geogr.), Assoc. Prof. of the Department of Recreational Geography, Country Studies and Tourism, Voronezh State University, Voronezh, Russian Federation, ORCID: https://orcid.org/0000-0003-1702-2276, e-mail: deanery@geogr.vsu.ru ронеж, Российская Федерация, ORCID:

https://orcid.org/0000-0003-1702-2276, e-mail: deanery@geogr.vsu.ru
(C) Zarytovskaya A. I., Derevyagina M. V., 2020

$\triangle$ Maria V. Derevyagina, e-mail: $\underline{\mathrm{m} \text { derevyagina@mail.ru }}$
Зарытовская Александра Ивановна
кандидат географических наук, доцент кафедры рекреационной географии, страноведения и туризма Воронежского государственного университета, г. Во(c) (i) The content is available under Creative Commons Attribution 4.0 License. 
Деревягина Мария Владимировна преподаватель кафедры социально-экономической географии и регионоведения Воронежского государственного университета, г. Воронеж, Российская Федерация, ORCID: https://orcid.org/0000-0002-7622-7258, e-mail: m derevyagina@mail.ru
Maria V. Derevyagina

Lecturer of the Department of Social and Economic Geography and Regional Studies, Voronezh State University, Voronezh, Russian Federation, ORCID:

https://orcid.org/0000-0002-7622-7258, e-mail: m derevyagina@mail.ru 